its resistance to a drug is in fact less likely than a variable esymmetrical division, with a decreasing probability of daughter cells arising with increasingly different resistance from that of the parent cell. From a statistical point of view, however, the simpler assumption, which lends itself more easily to the construction of the model, leads to much the seme conclusions.

It has also been implied that the resistance of a cell, once it has arisen from division of a parent cell, is constant. It has, however, been suggested that resistance varies throughout the life-cycle of a cell ${ }^{13}$. This again would not alter in any significant way the deductions from the theory. It would, however, mean that, with a given concentration of drug, cells of 'marginal' resistance would be more likely to be affected by the drug as their resistance varied during their growth. This would have two effects. First, there would be a rather more rapid shift to the right in the distribution curves of cells grown in the presence of drug than is suggested by Figs. 3 and 4 . Second, those concentrations of drug which coincide with a high proportion of cells of 'marginal' resistance would affect more cells than we have suggested, and cause an even greater effect on lag and on mean generation time.

It may be argued that the theory of clonal variation has no advantages over that of mutation, and indeed that the variations in resistance which we have described are due to mutational changes in the genetic constitution of the organism. It is true that one may take the view that the difference between these two theories is only one of terminology. But it is suggested that the insistence on the use of the term mutation to describe the continuous variations of resistance which exist in a culture distorts the meaning of this word. Mutation is normally used for describing a discrete discontinuous quantum-like change occurring in a small-usually a very smallproportion of organisms. Not only are the variations we described as clonal so small as to be capable of being regarded as continuous, but also they occur in a very large proportion of the cells. Indeed, the type of distribution of resistance occurring in a culture is such that there are almost as many cells of slightly higher or slightly lower resistance than the mode, as there are cells with modal resistance; there are altogether many more cells of resistance different from the modal than cells with modal resistance. As we have said earlier, it is most improbable that there could occur the vast number of small mutations which would account for the many degrees of resistance which cells may develop for many drugs.

There is, of course, no doubt that many of the properties of micro-organisms are genetically controlled, and that these may include the capacity to undergo variation such as enzyme adaptation and perhaps the capacity to become resistant to a drug. Nevertheless, the essential feature of reproduction in micro-organisms is that the reproductive material and the somatic material are identical. The whole of the dividing cell is represented in the two daughter cells. It is therefore quite conceivable-we have earlier said it is even quite probable-that division may not be completely symmetrical and the distribution of material from the parent cell to the daughter cells not exactly equal. In so far as this material includes the enzymatic systems or other mechanisms which constitute drug resistance, the daughter cells may therefore have a somewhat different resistance from that of the parent cell.
Finally, it should be reiterated that the hypothesis of clonal variation with selection does not imply that mutation or direct induction do not play a part in producing variations in cultures grown in specific chemical or other environments. It is suggested only that this mechanism might more readily explain some of the examples of acquired drug resistance. It is tempting to suppose that the easily induced changes in bacteria and especially viruses grown in specific hosts or specific tissues are also brought about by clonal variation with selection; but it remains to be seen whether the same mechanisms underlie these and other examples of induced variation.

I am grateful to Dr. S. E. Jacobs and Dr. J. Mandelstam for much helpful discussion during the formulation of the views here set out, and to Miss Joan Fleming for technical assistance in the experiments. I am especially indebted to Mr. L. Bihaly, who has given me invaluable help in the statistical aspects of this work and without whose constant advice and criticism this paper could not have been written.

1 Yudkin J., Biochem. J., 28, 1859 (1932) ; Biol. Rev., 13, 93 (1938).

Stephenson, M., and Yudkin, J., Biochem. J., 30, 506 (1936).

- Mandelstam, J., and Yudkin, J., Biochem. J., 51, 686 (1952).

- Lewis, I. M., J. Bact., 28, 619 (1934).

Demerec, M., J. Bact., 58, 63 (1948).

"Hinshelwood, C. N., "The Chemical Kinetics of the Bacterial Cell" (University Press, Oxford, 1946); Nature, 166, 1089 (1950); Bull. World Health Org., 6, 3 (1952).

2 Demerec, M., Proc. U.S. Nat. ${ }^{-}$Acad. Sci., 31, 16 (1945).

8 Davies, D. S., Hinshelwood, C. N., and Pryce, J. M. G., Trans. Faraday Soc., 41, 778 (1945).

-Atwood, K. C., Schneider, L. K., and Ryan. F. J., Proc. U.S. Nat. Acad. Sci., 37, 146 (1951).

${ }^{10}$ Ryan, F. J., J. Gen. Microbiol., 7, 69 (1952).

11 Hughes, W. H., J. Gen. Microbiol., 8, 175 (1952).

12 Mandelstam, J., and Yudkin, J. (to be published).

is Hinshelwood, C. N., Nature, 167, 666 (1951).

\section{NEW FELLOWS OF THE ROYAL SOCIETY}

A ' $\mathrm{I}$ ' the meeting of the Royal Society on March 19 , A the following were elected to fellowship :

Dr. J. S. ANDErson, deputy chief scientific officer, Atomic Energy Research Establishment, Harwell, distinguished for his contributions to inorganic chemistry, particularly in connexion with the chemistry of the metal carbonyls, complex salts, and non-stoichiometric compounds.

DR. KENNETH BAILEY, assistant director of research in the Department of Biochemistry and Fellow of Trinity College, Cambridge, distinguished for his biochemical researches on the proteins of muscle.

Prof. H. Barcroft, professor of physiology, Sherrington School of Physiology, St. 'Thomas's Hospital, London, S.E.l, distinguished for investigations respecting the blood supply to human muscles.

Dr. J. BARKER, reader in plant physiology, University of Cambridge, distinguished for investigations on the carbohydrate metabolism of plant storage tissues.

DR. J. C. BurkrLL, university lecturer in mathematics, University of Cambridge, distinguished for his researches in analysis, especially in the theory of integration, also for his contributions to the theory of trigonometrical series. 
DR. J. W. CORNFORTH, research chemist, National Institute for Medical Research, distinguished for his fundamental contributions to the chemistry of penicillin and its degradation products and to the chemistry of the oxazole group, and for the total synthesis of the androgenic hormones.

Dr. S. C. Curran, senior lecturer, Department of Natural Philosophy, University of Glasgow, distinguished for his contributions to electronic counting techniques, and for his researches upon the emission of $\beta$ - and $\gamma$-rays by atomic nuclei.

C. S. Elton, director of the Bureau of Animal Population, Oxford, distinguished for his pioneer work in the field of animal ecology as founder of the Bureau of Animal Population and of the Journal of Animal Ecology.

Dr. O. H. Frankel, chief of the Division of Plant Industry, Commonwealth Scientific and Industrial Research Organization, Australia, distinguished for his combined genetical and cytological studies on economic plants.

DR. E. F. GALE, reader in chemical microbiology, University of Cambridge, distinguished especially for his work on the amino-acid metabolism of bacteria and the effect thereon of penicillin and other chemotherapeutic agents.

Dr. A. G. Gaydon, Warren Research Fellow of the Royal Society, Imperial College of Science and Technology, London, distinguished for his researches on the spectra of flames, which have gone far in elucidating the mechanism of flame reactions under the most varied conditions.

DR. A. A. HALL, director of the Royal Aircraft Establishment, Farnborough, distinguished for his contributions to the theory and design of aircraft and their equipment.

Prof. G. W. Harris, Fitzmary professor of physiology, Institute of Psychiatry, University of London, distinguished for his contributions to the physiology of the hypothalamus and pituitary body.

Sir Claude Inglis, director of hydraulics research, Department of Scientific and Industrial Research, distinguished for his pioneer work in studying hydraulics by the use of scale models, and for the application of these techniques to hydraulic problems in India.

Prof. WIrlis JACKson, professor of electrical engineering, Imperial College of Science and Technology, London, distinguished for his studies of the electrical behaviour of dielectrics and of the performance of transmission lines and wave-guides.

Prof. M. J. Lighthitl, Beyer professor of applied mathematics, University of Manchester, distinguished for his researches in fluid dynamics, especially in non-linear problems of compressible flow, in supersonic boundary layer theory and in shock wave theory.

Dr. G. H. MItchell, a principal scientific officer, Geological Survey of Great Britain, distinguished for his researches in palæozoic stratigraphy.

Prof. L. S. Penrose, Galton professor of eugenics, University of London, distinguished especially for his study of the factors responsible for mental deficiency and for inheritance studies in man.

A. R. Powell, research manager, Johnson Matthey and Co., Ltd., distinguished for his contribution to analytical chemistry and the chemistry and metallurgy of the rarer metals, which has led to important developments in methods for the extraction of platinum ores and the production of very pure metals.

DR. H. M. Powell, reader in chemical crystallography, University of Oxford, distinguished for his elucidation of problems of chemical constitution by $\mathrm{X}$-ray methods, especially of organo-metallic and clathrate compounds.

LORD ROTHSCHILD, assistant director of research in the Department of Zoology, University of Cambridge, distinguished for his investigations into the process of fertilization and the physiology of reproduction.

Dr. D. Shoenßerg, reader in physics, University of Cambridge, distinguished for his researches in the field of low temperatures, especially upon superconductivity and the magnetic properties of metals.

Prof. T. WALLACE, professor of horticultural chemistry, University of Bristol, and director of the H.orticultural Research Station, Long Ashton, distinguished for his studies of mineral nutrition of horticultural crops especially in respect to diagnosis of deficiencies.

Prof. D. Whitteridge, professor of physiology, University of Edinburgh, distinguished especially for his studies of the nerves of thcracic viscera and of the external muscles of the eye.

DR. R. VAN DER R. WOOLLEX, director of the Commonwealth Observatory, Australia, distinguished for his work on the formation of absorption lines and on convective processes in the solar atmosphere.

\section{NEWS and VIEWS}

\section{Elihu Thomson (1853-1937)}

BorN in Manchester a century ago, on March 29, 1853; the son of a skilled mechanic, Elihu Thomson, pioneer in the practical applications of electricity, emigrated with his family to the United States at the age of five. After finishing his education at the Central High School, Philadelphia, he was appointed professor of mechanics and chemistry at that institution in 1876. Four years later he became chief electrician to the American Electric Company, and with Edward J. Houston founded the ThomsonHouston Company at Lynn, Massachusetts. By its merger with the Edison General Electric Company in 1892, the General Electric Company of America was formed - the largest manufacturing company of electric equipment in the world, which was to operate more than six hundred patents connected with Thomson's inventions. As director of the firm's research laboratories, Thomson discovered that the resistance of the electric arc is inversely proportional to the current passing through it, constructed the first arc-light dynamo with an automatic regulator, and was the first to use a magnetic field to move an electric arc-the principle on which magnetic blowout switches opərate. He also invented the incandescent method of electric welding, the electric watt-hour meter, and a system of colour photography. His nam $r$ is given to the repulsion of a metal ring from the poles of an alternating-field electromagnet. Radiology owes to his ingenuity the first stereoscopic $\mathrm{X}$-ray pictures. Thomson received medals from most of the learned societies of the world: the Rumford 